\title{
Optimization of Distribution Cost (a case study in PT. Zamrud Bumi Indonesia)
}

\author{
Shilvaisnaeni Nurcesar Regia ${ }^{1)}$; Robi Awaluddin ${ }^{2)}$;Ayus Ahmad Yusuf ${ }^{3)}$ \\ 1) University Kuningan \\ 2) University Kuningan \\ 3) IAIN Syekh Nurjati Cirebon \\ Email: ${ }^{1)}$ regiashilvaa@gmail.com; ${ }^{2)}$ awaluddin.robi@uniku.ac.id ; \\ 3) ayusahmadyusuf@gmail.com
}

\section{How to Cite :}

Regia, S. N., Awaluddin, R., Yusuf, A. A. 2021. Optimizing of Distribution Cost (a Case Study in PT. Zamrud Bumi Indonesia). Journal of Agri Socio Economics and Business. 3 (2): 69-80. DOI: https://doi.org/10.31186/jaseb.3.2.69-80

\section{ARTICLE HISTORY}

Received [03 Sept 2021]

Revised [08 Nov 2021]

Accepted [21 Nov 2021]

\section{KEYWORDS}

Transportation Method, Least Cost Method, Modified Distribution Method

This is an open access article under the $\underline{C C-B Y-S A}$ license

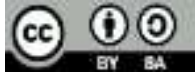

\section{ABSTRACT}

PT. Zamrud Bumi Indonesia is a manufacturing company engaged in the processing of multipurpose liquid organic agricultural fertilizer branded Power Bumi. Distribution from warehouses to destinations that vary in distance resulted in different distribution cost budgets. Transportation models can help solve the problem of distributing products from multiple warehouses to multiple destination cities and reduce total distribution costs. This study aims to find out the total minimum cost of distribution by using the Least Cost method as the initial solution and knowing the test results of MODI method as the optimum solution at PT. Zamrud Bumi Indonesia. The results of this study showed that before using the Transportation Method, the company incurred a distribution fee of Rp. 11.600.000, - in December 2020, after using the Least Cost transportation method as the initial solution of distribution costs incurred in the amount of Rp. 9.981.250,- and modi transportation method as the optimum test resulted in the same value of $R p$. $9,981,250$. So the company saves distribution costs of $R p$. 1.618.750, - every month.

\section{INTRODUCTION}

Manufacturing companies are generally established to make the most profit as possible and also to maintain the company's survival so that the company can grow as expected in the future. In manufacturing activities, distribution is an important role in ensuring the products to be distributed so that the product is available evenly in each city or region. Product distribution is the most important aspect so it needs to be 
managed properly and the one that needs to be considered in the distribution of products is transportation.

PT. Zamrud Bumi Indonesia located in Cibingbin Subdistrict, Kuningan Regency is a manufacturing company engaged in the processing of multipurpose liquid organic agricultural fertilizer branded Power Bumi. The amount of distribution carried out by the company to various regions in Indonesia requires the company to pay attention to transportation problems in terms of cost, length of delivery and vehicles used. The vehicle used by the company is a pick-up box.

The purpose of this research is to generate the minimum distribution costs using the Least Cost Transportation Method as the initial solution and the MODI Transportation Method as the optimum test. Those method can be used as a solution to this problem phenomenon with linear program calculation techniques so that maximum profit can be achieved by the company (Yunistira, 2019).

Nabila (2017) pointed out in her research said that if the company in fulfilling the activities of product distribution can not allocate its products appropriately and does not use the calculation of transportation models so that the cost of distribution incurred by the company in delivering its products has not been effective, then the company can experience swelling costs and can not reduce transportation costs, if this is allowed then the company will mi losses so as not to get the maximum profit from transportation costs.

Meanwhile at the results of the study (Pertiwi et al., 2020) in his study entitled "Optimizing The Cost of Transportation Distribution of Subsidized Fertilizer Using Transportation Model" stated that the application of transportation model using two steps, namely determining the initial solution using the Least Cost method and determining the optimum solution with modified distribution (MODI) method. Those can optimize the total transportation cost for subsidized fertilizer distribution and save costs.

Meanwhile at the results of the study (Niki, 2016) in his research entitled "Application of Transportation Delivery of Goods Using the Least Cost and MODI Method on CV. Nihta Cargo Express". The results of this study stated that the application of freight transport application can describe the cost of the delivery process so that it can evaluate transportation problems.

Meanwhile at the results of the study (Setiyaji, 2016) in his research entitled "Optimization Analysis of Goods Delivery Using Transportation Method Empirical Study Of Delivery Between Factories to Warehouses at PT. Tirta Investama Klaten". Stating the use of the Least Cost and MODI methods can reach the minimum value of transportation cost reduction of Rp. 6,950,000.

Meanwhile at the research conducted by (Sidabutar, 2020) in his research entitled "Optimization of Rice Distribution Costs in Perum Bulog Sub Drive Medan". Saying that the use of the Least Cost method followed by stepping stone method can provide optimal results, not only with MODI method.

Research conducted by (Kartika, 2019) entitled "Optimization of Distribution with Transportation Methods at The X Indah Factory" said that the application of transportation models using the Least Cost and MODI methods can reduce transportation costs by Rp. 5,500,000

The results of the study (Kusumawardani, 2018) entitled "Optimization of Transportation Cost Using Genetic Algorithm". This study uses a combination of North West Corner and MODI methods to minimize transportation costs. 
The results of the study (Sam, 2017) in his research entitled "Optimization of Product Distribution by Transportation Method Based on Product Demand at PT. XYZ Surabaya". The results of the study prove that transportation methods can minimize the cost of distribution. This research uses VAM method and Least Cost method as initial solution and MODI method for optimum test.

The results of the study (Zainuddin, 2011) in his research entitled "Analysis of the Application of Transportation and Distribution Model at PT. Coca-Cola Bottling Indonesia" in this study the method used as an initial solution is the VAM method and modi method as the optimal test is proven to also minimize transportation costs.

Research conducted (Rosyidi, 2006) in his research entitled "Planning Distribution Lines with Transportation Methods to Minimize The Cost of Case Study Delivery at PT. Blambangan Foodpacker Indonesia Banyuwangi". The results of this study stated that the application of transportation model can save the cost of transportation distribution, in this study the method used is the North West Corner method as the initial solution and MODI as the optimum test.

The results of the study (Aditya \& Saputra, 2020) in his research entitled "Optimization of Transportation Costs of Distribution of Swab Test Covid-19 Equipment (Pt. Case Study. BATARA HUSINDO RAYA) said that in addition to modi method of applying the Least Cost and Stepping Stone method can minimize distribution costs.

The results of the study (Soplanit et al., 2019) in his study entitled "Optimization Of Material Distribution Costs With Combination Of Nwc (North West Corner) And Modi ( Modified Distribution) Methods On Bridge Construction Projects In North Sulawesi" said that the combination of methods in this study can save transportation costs.

The results of the study (Ariyantini, 2017) in his study entitled "Optimization of Transportation Costs of Distribution of Bottled Drinking Water (AMDK) on CV. Karunia Jaya Bondowoso" said that not only the combination of least cost method but the application of VAM and MODI method can also minimize the transportation cost of AMDK distribution

\section{RESEARCH METHODS}

\section{Transportation Model Theory}

According to (Render, 2007) transportation modeling is looking for the cheapest way to deliver goods from multiple sources to multiple destinations. To use the transportation model, we must know the following:

1. Point of origin and capacity of supply at any period.

2. Point of destination and demand at each period.

3. Delivery cost of one unit from each point of origin to the point of destination.

An overview of the transportation model is a product to be sent from several sources to several destinations, each with a known level of demand. In this case it can be described as in the following figure: 


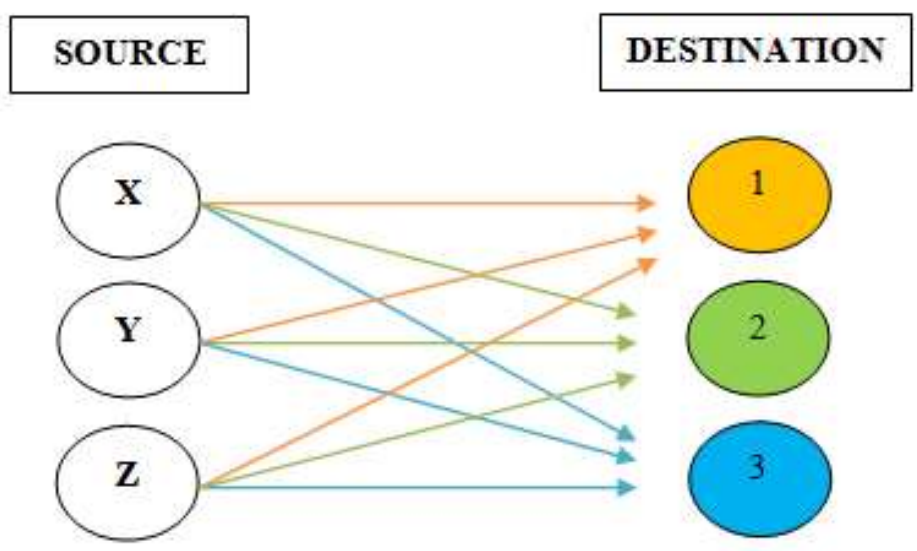

The transport model uses the means of a table to provide an overview of the distribution case, the following general form of transport table in the following table:

\begin{tabular}{|c|c|c|c|c|}
\hline & Destination 1 & Destination 2 & Destination 3 & Supply \\
\hline \multirow{2}{*}{ Source A } & $X_{11}$ & $X_{12}$ & $X_{13}$ & \multirow{2}{*}{ S1 } \\
\hline & $\mathrm{C}_{11}$ & $\mathrm{C}_{12}$ & $\mathrm{C}_{13}$ & \\
\hline Source B & $\underline{X}_{21}$ & $\mathrm{X}_{22}$ & $\mathrm{X}_{23}$ & S2 \\
\hline \multirow[b]{2}{*}{ Source C } & $\mathrm{C}_{21}$ & $C_{22}$ & $\frac{C_{23}}{X_{23}}$ & \multirow[b]{2}{*}{ S3 } \\
\hline & $C_{31}$ & $\mathrm{C}_{32}$ & $\mathrm{C}_{33}$ & \\
\hline Demand & D1 & D2 & D3 & $\sum_{i=1}^{\infty} S i=\sum_{j=1}^{\infty}$ \\
\hline
\end{tabular}

Information:

$X$ : Number of goods delivered from source to destination

C : Cost of delivery of goods from source to destination

S : Warehouse capacity

D : Destination capacity

The method to facilitate the company in determining the allocation of products is to use transportation methods. Transportation methods can be described as follows:

\section{A. Least Cost Method}

The initial procedure for solving transportation problems when using the smallest or lowest cost method is to allocate as high as possible a number of commodities in the cell that have the smallest unit cost in the whole table. If there are multiple cells that have the same smallest unit cost then select one of them in a balanced manner. Cross a column or row that has been fulfilled, if both columns and rows are simultaneously filled only one is crossed. After adjusting the supply and demand for all rows and columns that have not been crossed, repeat the process by giving the highest possible value to the cell that has the next smallest unit cost that has not been crossed. This procedure is completed when exactly one row or column has not been crossed. 


\section{B. MODI Method}

If the initial solution has been obtained, then the next step is to determine whether the solution is already the best (the cheapest cost) or not. In general it can be formulated to calculate row and column values:

Information:

$$
C i j=R \mathbf{i}+K \mathbf{j}
$$

$\mathrm{Cij}=$ cost in cell ij (rectangle at intersection of row $\mathrm{i}$ and column $\mathrm{j}$ )

$\mathrm{Ri}=$ value charged to line $\mathrm{i}$

$\mathrm{Kj}=$ value charged to column $\mathrm{j}$

After calculating all row and column values, the next step in the MODI method is to evaluate each blank cell in the breakdown, which is to calculate the corrective index. The formulas used in calculating the repair index are:

\section{Repair Index $=\mathbf{C} \mathbf{i j}-\mathbf{R} \mathbf{i}-\mathbf{K} \mathbf{j}$}

\section{Place and Time}

This research was conducted at PT. Zamrud Bumi Indonesia located in Cibingbin District, Kuningan Regency, West Java. This research was conducted for 2 months, namely in February 2021 until April 2021.

\section{Data Analysis Techniques}

This study uses transportation model with 2 steps method namely Least Cost as the initial solution and MODI as the optimum test. With the following steps:
a. Collect data from companies
b. Create a transport start table
c. Determining transportation problems from various sources and various purposes
d. Application of Least Cost method as the initial solution to transportation problems
e. Define modi method as optimum test
f. conclusion.

\section{RESULTS AND DISCUSSION}

\section{Distribution Data}

PT. Zamrud Bumi Indonesia has three warehouses that will send its products to the distributor region, shipping products from the warehouse using pick-up boxes that have been provided by the company. The location of the warehouse is in the area of Sukarapih, Sukamaju and Cibingbin while the area of the delivery destination is Karawang, Indramayu, Majalengka, Subang and Sukabumi.

Based on the data obtained in the research then compiled the flow of delivery of goods from the warehouse to the destination of delivery. The data on distribution of multipurpose organic liquid fertilizer products branded with earth power in December 2020 are as follows: 
1. Warehouse capacity/capacity data

\begin{tabular}{|c|c|}
\hline Warehouse & Capacity (Box) \\
\hline Sukarapih & 600 \\
\hline Sukamaju & 700 \\
\hline Cibingbin & 500 \\
\hline Sum & $\mathbf{1 8 0 0}$ \\
\hline
\end{tabular}

Source : PT. Zamrud Bumi Indonesia, December 2020

2. Data capacity / capacity of the destination city (distributor)

\begin{tabular}{|c|c|}
\hline Destination City & Capacity (Box) \\
\hline Karawang & 400 \\
\hline Indramayu & 500 \\
\hline Majalengka & 350 \\
\hline Subang & 300 \\
\hline Sukabumi & 250 \\
\hline Sum & $\mathbf{1 8 0 0}$ \\
\hline
\end{tabular}

Source : PT. Zamrud Bumi Indonesia, December 2020

3. Transportation Cost Data from Warehouse to Destination City

\begin{tabular}{|c|l|r|r|}
\hline Warehouse & $\begin{array}{c}\text { Destination } \\
\text { City }\end{array}$ & Cost (Rp) & $\begin{array}{c}\text { Cost } \\
\text { (Rp)/Box }\end{array}$ \\
\hline \multirow{4}{*}{$\begin{array}{c}\text { Warehouse } \\
\text { Sukarapih }\end{array}$} & Karawang & 700,000 & 5,932 \\
\cline { 2 - 4 } & Indramayu & 500,000 & 4,310 \\
\cline { 2 - 4 } & Majalengka & 500,000 & 5,000 \\
\cline { 2 - 4 } & Subang & 600,000 & 7,500 \\
\cline { 2 - 4 } & Sukabumi & $1,100,000$ & 9,322 \\
\hline \multirow{4}{*}{$\begin{array}{c}\text { Wukamaju } \\
\text { Sukehouse }\end{array}$} & Karawang & $1,400,000$ & 6,086 \\
\cline { 2 - 4 } & Indramayu & 500,000 & 4,545 \\
\cline { 2 - 4 } & Majalengka & 500,000 & 4,761 \\
\cline { 2 - 4 } & Subang & 600,000 & 6,000 \\
\cline { 2 - 4 } & Sukabumi & $1,100,000$ & 9,166 \\
\hline \multirow{4}{*}{$\begin{array}{c}\text { Cibingbin } \\
\text { Warehouse }\end{array}$} & Karawang & $1,400,000$ & 5,833 \\
\cline { 2 - 4 } & Indramayu & 500,000 & 4,347 \\
\cline { 2 - 4 } & Majalengka & 500,000 & 4,854 \\
\cline { 2 - 4 } & Subang & 600,000 & 5,000 \\
\cline { 2 - 4 } & Sukabumi & $1,100,000$ & 13,750 \\
\hline & \multicolumn{1}{|c|}{ Sum } & $11,600,000$ & \\
\hline
\end{tabular}

*calculation of cost per box attached in the attachment 
4. Distribution Flow from Warehouse to Destination

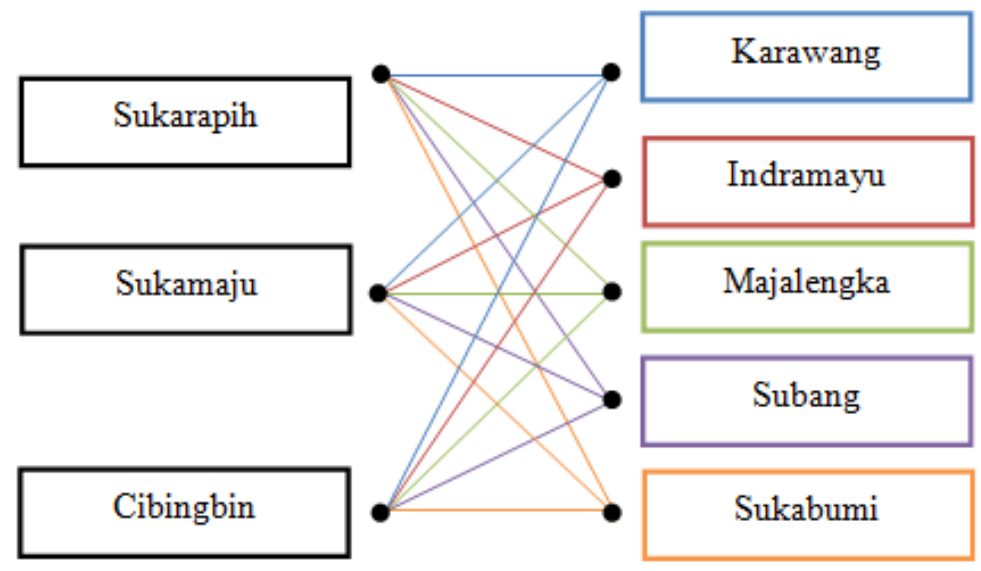

\section{Initial Settlement with The Least Cost Method}

In this method are performed procedural steps as described below.

a. Select the Xij (box) variable with the smallest transportation cost (Cij) and allocate as much as possible. If there are 2 smallest costs of the same choose one.

b. Continue this process until all supply and demand are met.

The resolution can be seen in the following table:

\begin{tabular}{|c|c|c|c|c|c|c|}
\hline Source & Karawang & Indramayu & Majalengka & Subang & Sukabumi & Supply \\
\hline \multirow[b]{2}{*}{ Sukarapih } & 5,932 & 4,310 & 5,000 & 7,500 & 9,322 & \multirow[b]{2}{*}{600} \\
\hline & 100 & 500 & $X$ & $x$ & $x$ & \\
\hline \multirow[b]{2}{*}{ Sukamaju } & 6,086 & 4,545 & 4,761 & 6,000 & 9,166 & \multirow[b]{2}{*}{700} \\
\hline & 100 & $x$ & 350 & $\mathrm{x}$ & 250 & \\
\hline \multirow[b]{2}{*}{ Cibingbin } & 5,833 & 4,347 & 4,854 & 5,000 & 13,750 & \multirow[b]{2}{*}{500} \\
\hline & 200 & $\mathrm{x}$ & $x$ & 300 & $x$ & \\
\hline Demand & 400 & 500 & 350 & 300 & 250 & 1800 \\
\hline
\end{tabular}

From the completion table above the most allocation starts from sukarapih warehouse to Indramayu so that it consumes demand. Then from sukamaju warehouse to Majalengka which has the next smallest cost is done allocation. Next take the same steps until the demand and supply are met. 
So from the table above, it can be calculated the total cost obtained from the Least Cost Method as follows:

$$
\begin{aligned}
& \mathrm{Z}=\sum_{\substack{i=1 \\
3}}^{m} \sum_{\substack{j=1 \\
5}}^{m} C_{i j} X_{i j} \\
& \mathrm{Z}=\sum_{i=1}^{3} \sum_{j=1}^{5} C_{i j} X_{i j} \\
& Z=\left(C_{11}\right)\left(X_{11}\right)+\left(C_{12}\right)\left(X_{12}\right)+\left(C_{21}\right)\left(X_{21}\right)+\left(C_{23}\right)\left(X_{23}\right)+\left(C_{25}\right)\left(X_{25}\right)+\left(C_{31}\right)\left(X_{31}\right)+ \\
& \left(\mathrm{C}_{34}\right)\left(\mathrm{X}_{34}\right) \\
& Z=(5,932)(100)+(4,310)(500)+(6,086)(100)+(4,761)(350)+(9,166)(250)+ \\
& (5,833)(200)+(5,000)(300) \\
& Z=\text { Rp. 9.981.250,- }
\end{aligned}
$$

\begin{tabular}{|c|c|c|c|c|}
\hline \multicolumn{5}{|c|}{$\mathrm{C}_{11}$ (Sukarapih ke Karawanq) } \\
\hline C & $=$ & $U$ & + & V \\
\hline 5932 & $=$ & 0 & + & V \\
\hline \multirow[t]{2}{*}{ V } & $=$ & 5932 & - & 0 \\
\hline & $=$ & 5932 & & \\
\hline \multicolumn{5}{|c|}{$\mathrm{C}_{12}$ (Sukarapih ke Indramayu) } \\
\hline C & $=$ & $U$ & + & $\mathrm{V}$ \\
\hline 4310 & $=$ & 0 & + & V \\
\hline \multirow[t]{2}{*}{ V } & $=$ & 4310 & - & 0 \\
\hline & $=$ & 4310 & & \\
\hline \multicolumn{5}{|c|}{$\mathrm{C}_{21}$ (Sukamaju ke Karawang) } \\
\hline C & $=$ & $U$ & + & $\mathrm{V}$ \\
\hline 6086 & $=$ & $U$ & + & 5932 \\
\hline$U$ & $=$ & 6086 & - & 5932 \\
\hline U & $=$ & 154 & & \\
\hline \multicolumn{5}{|c|}{$\mathrm{C}_{23}$ (Sukamaju ke Majalengka) } \\
\hline C & $=$ & $U$ & + & V \\
\hline 4761 & $=$ & 154 & + & V \\
\hline
\end{tabular}

\section{Optimal Completion by MODI Method}

To determine the optimal solution with the MODI method, the initial solution used is the Least Cost method and can be searched ui values for each row and $\mathrm{Vj}$ value for each column with the formula $\mathrm{Ui}+\mathrm{Vj}=\mathrm{Cij}$ by specifying the value $\mathrm{Ui}=0$.

Then the other row and column values can be searched by formula $\mathrm{C}=\mathrm{U}+\mathrm{V}$ (only for filled cells) as follows:

\begin{tabular}{ccccc}
$\mathrm{V}$ & $=$ & 4761 & - & 154 \\
$\mathrm{~V}$ & $=$ & 4607 & & \\
\hline $\mathrm{C}_{25}$ (Sukamaju & ke Sukabumi) \\
\hline $\mathrm{C}$ & $=$ & $\mathrm{U}$ & + & $\mathrm{V}$ \\
9166 & $=$ & 154 & + & $\mathrm{V}$ \\
$\mathrm{V}$ & $=$ & 9166 & - & 154 \\
$\mathrm{~V}$ & $=$ & 9012 & & \\
\hline $\mathrm{C}_{31}$ (Cibingbin & ke Karawang) \\
\hline $\mathrm{C}$ & $=$ & $\mathrm{U}$ & + & $\mathrm{V}$ \\
5833 & $=$ & $\mathrm{U}$ & + & 5932 \\
$\mathrm{U}$ & $=$ & 5833 & - & 5932 \\
$\mathrm{U}$ & $=$ & -99 & & \\
\hline $\mathrm{C}_{34}($ Cibingbin ke Subang) \\
\hline $\mathrm{C}$ & $=$ & $\mathrm{U}$ & + & $\mathrm{V}$ \\
5000 & $=$ & -99 & + & $\mathrm{V}$ \\
$\mathrm{V}$ & $=$ & 5000 & - & $(-99)$ \\
$\mathrm{V}$ & $=$ & 5099 &
\end{tabular}

76 | Regia, S. N., Awaluddin, R., Yusuf, A. A. Optimizing of Distribution Cost... 
After determining the values of rows and columns, then create a table of row and column values that have been calculated above, the table is presented as follows:

\begin{tabular}{|c|c|c|c|c|c|c|}
\hline Source & $\begin{array}{l}\text { Karawang } \\
\mathrm{V}_{1}=5,932\end{array}$ & $\begin{array}{l}\text { Indramayu } \\
\mathrm{V}_{2}=4,310\end{array}$ & $\begin{array}{l}\text { Majalengka } \\
V_{3}=4,607\end{array}$ & $\begin{array}{c}\text { Subang } \\
\mathrm{V}_{4}= \\
5,099\end{array}$ & $\begin{array}{l}\text { Sukabumi } \\
V_{5}=9,012\end{array}$ & Supply \\
\hline \multirow{2}{*}{$\begin{array}{c}\text { Sukarapih } \\
\mathrm{U}_{1}=0\end{array}$} & 5,932 & 4,310 & 5,000 & 7,500 & 9,322 & \multirow[b]{2}{*}{600} \\
\hline & 100 & 500 & $X$ & $x$ & $x$ & \\
\hline \multirow{2}{*}{$\begin{array}{l}\text { Sukamaju } \\
\mathrm{U}_{2}=154\end{array}$} & 6,086 & 4,545 & 4,761 & 6,000 & 9,166 & \multirow[b]{2}{*}{700} \\
\hline & 100 & $x$ & 350 & $x$ & 250 & \\
\hline \multirow{2}{*}{$\begin{array}{l}\text { Cibingbin } \\
U_{3}=-99\end{array}$} & 5,833 & 4,347 & 4,854 & 5,000 & 13,750 & \multirow[b]{2}{*}{500} \\
\hline & 200 & $x$ & $x$ & 300 & $x$ & \\
\hline Demand & 400 & 500 & 350 & 300 & 250 & 1800 \\
\hline
\end{tabular}

After creating a table of row and column values, next look for the repair index of each non-base variable with the formula $\mathrm{Kij}=\mathrm{Cij}-\mathrm{Ui}-\mathrm{Vj}$ (only for blank cells) as follows:

$\mathrm{K} 13=5000-0-4607=393$

$\mathrm{K} 14=7500-0-5099=2401$

$\mathrm{K} 15=9322-0-9012=310$

$\mathrm{K} 22=4545-154-4310=81$

$\mathrm{K} 24=6000-154-5099=747$

$\mathrm{K} 32=4347-(-99)-4310=136$

$\mathrm{K} 33=4854-(-99)-4607=346$

$\mathrm{K} 35=13750-(-99)-9012=4837$

Based on the calculation results above it appears that the value of Kij is positive all and there is no value of Kij that is negative, meaning it has produced an optimal settlement in this problem and does not need to be allocated anymore because it will cause a rise in costs. If the Kij value is negative then the MODI method replaced with stepping stone method means that there is addition and reduction of allocation in each filled cell. Both methods produced the same result of Rp. 9,981,250,--. So in this matter proves that by using the Least Cost method and MODI method can save transportation costs at PT. Zamrud Bumi Indonesia amounting to Rp. 1.618.750,- (Rp. 11.600.000 Rp. 9.981.250). The comparison of the calculation results before the implementation and after the application of the transport model is illustrated in the following line diagram image: 


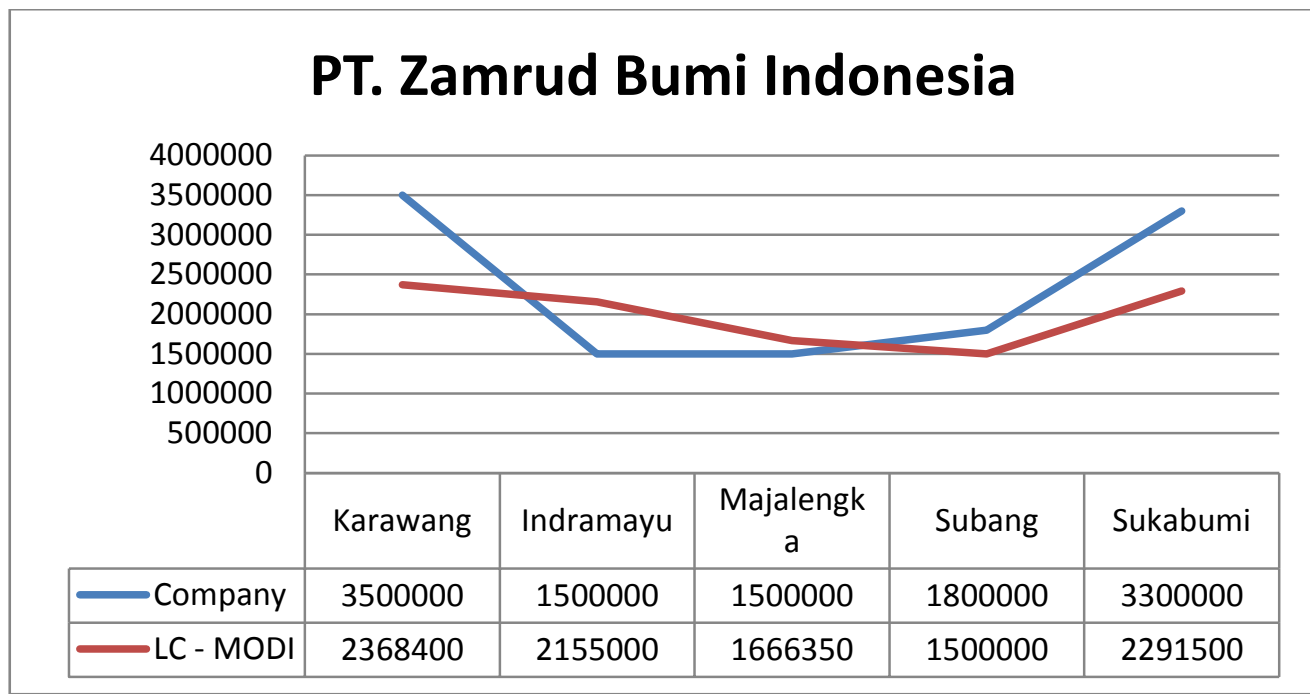

Tables above shows that the cost of distributing products in PT. Zamrud Bumi Indonesia from warehouses to several destinations carried out by the company (blue line) and the results of calculations using the Least Cost method and modi method (red line) there was a significant decrease in costs. This can be seen from the total cost incurred at the time of delivery of goods per month. However, in other destinations there was a slight increase as the number of product shipments increased.

From the explanation above it can be interpreted that the use of the Least Cost method and MODI method can lower the cost of shipping from the warehouse to the destination city of Karawang, Subang and Sukabumi because the results of the calculation of transportation methods reduce the number of product shipments. However, on delivery from the warehouse to the destination city of Indramayu and Majalengka experienced an increase in shipping costs, this is because in the process of calculating the transportation model increases the number of product shipments, but this increase is not very significant so it does not change the end result.

PT. Zamrud Bumi Indonesia in the distribution of its products from warehouse to city distributors apply conventional methods that are benchmarking, so that the distribution costs incurred by the company has not been optimal in this case at a certain time of distribution between transportation costs incurred and products to be distributed unbalanced. Therefore, the use of transportation model using the smallest cost method and MODI method deserves to be a more optimal and efficient solution compared to the method previously applied by the company.

\section{CONCLUSIONS AND POLICY IMPLICATIONS}

\section{Conclusions}

From the discussion above, it can be concluded that the transportation method applied by PT. Zamrud Bumi Indonesia still uses conventional methods that benchmarking methods that have been applied by the company. So the distribution 
costs incurred by PT. Zamrud Bumi Indonesia is not optimal. Therefore, the conclusions that can be drawn by the authors in this study are as follows:

1 The results of the calculation using the Least Cost method as the initial solution proved to minimize the cost of distribution, with a total cost of Rp. 9.981.250,- while the cost of distribution carried out by the company using conventional methods patok duga rp. $11.600 .000,-$ so that the difference obtained by Rp. 1.618.750,- and this is a considerable decrease in load.

2 The calculation results using modi method show that the calculation on the initial solution using Least Cost method has been optimal because there is no negative value calculation result.

3 The calculation result using the least cost method combination as the initial solution and MODI method as optimum test showed the same result, so there is no comparison of distribution costs because the Kij value calculated using modi method shows a positive result.

So for distribution problems in PT. Zamrud Bumi Indonesia in this case the use of the Least Cost method and MODI method deserves to be a more optimal solution, compared to the method previously applied by the company.

\section{Recommendations}

From the results of research and discussion in this study, the suggestions that can be given are:

1 The author advises the company to be able to consider the application of transportation model in regulating distribution allocation activities.

2 The author suggests to those who want to continue their research using transportation model. For further research, research can be done with unbalanced issues, namely variable demand and supply on transportation problems are not the same number. It is expected that research with unbalanced issues can find out the most efficient methods on transportation problems that have unbalanced variables between supply and demand.

\section{REFERENCES}

Aditya, B. D., \& Saputra, B. S. (2020). Optimalisasi Biaya Transportasi Pendistribusian Alat Swab Test Covid-19 Menggunakan Model Transportasi Metode Stepping Stone( Studi. 2(1), 33-35. http://jim.unindra.ac.id/index.php/baiet/article /view/3958

Agustina, A. S., \& R. F. (2020). Perbandingan Metode Rt-Pcr Dan Tes Rapid Antibodi Untuk Deteksi Covid-19. Jurnal Kesehatan Manarang, 47-54.

Ariyantini, M. D. (2017). Digital Digital Repository Repository Universitas Universitas Jember Jember Staphylococcus aureus Digital Digital Repository Repository Universitas Universitas Jember Jember. Skripsi. https://repository.unej.ac.id /handle/123456789/97586

Coley, D. A., 1999, An Introduction to Genetic Algorithms for Scientists and Engineers. Singapore: World Scientific. 
Diah Purnama Sari. 2013. Optimasi Masalah Transportasi Menggunakan Metode Potensial Pada Sistem Distribusi PT. Mega Eltra Persero Cabang Medan. Jurnal Matematika. Medan: Universitas Sumatera Utara.

Kartika, R. (2019). Optimasi Distribusi dengan Metode Transportasi pada Pabrik The X Indah.

Kusumawardani, R. (2018). Optimization of Transportation Cost Using Genetic Algorithm.

Nabila, E. (2017). Universitas Katolik Parahyangan Fakultas Ilmu Sosial dan Ilmu Politik Program Studi Ilmu Administrasi Publik. Universitas Katolik Parahyangan. http://repository.unpar.ac.id/bitstream/handle/123456789/2025/Cover - Bab 1 - 3111061sc-p.pdf?sequence $=1$ \&isAllowed $=y$

Niki. (2016). Aplikasi Transportasi Pengiriman Barang Menggunakan Metode Least Cost dan MODI pada CV. Nihta Cargo Express.

Pertiwi, N., Jaya, A. I., \& Hajar. (2020). Optimalisasi Biaya Transportasi Pendistribusian Pupuk Bersubsidi Menggunakan Model Transportasi Metode Modified Distribusition (MODI). Matematika Dan Terapan, 17(2), 160-168. https://bestjournal.untad.ac.id/index.php/JIMT/article/view/15337/11394

Render, H. J. \& B. (2007). Manajemen Operasi (Edisi Kese). Salemba Empat.

Rosyidi. (2006). Perencanaan Jalur Distribusi dengan Metode Transportasi untuk Meminimumkan Biaya Pengiriman Studi Kasus di PT. Blambangan Foodpacker Indonesia Banyuwangi.

Salim, H. A. Abbas. 2002. Manajemen Transportasi. Jakarta: PT. Raja Grafindo Persada.

Sam, A. (2017). Optimasi Distribusi Produk dengan Metode Transportasi Berdasarkan Permintaan Produk di PT. XYZ Surabaya.

Setiyaji, W. (2016). Analisis Optimasi Pengiriman Barang Menggunakan Metode Transportasi Studi Empirik Deliveri Antar Pabrik ke Gudang pada PT. Tirta Investama Klaten.

Sidabutar, T. Y. (2020). Optimasi Biaya Distribusi Beras pada Perum Bulog Sub Drive Medan.

Soplanit, P. P. G., Dundu, A. K. T., \& Mangare, J. B. (2019). Optimasi Biaya Distribusi Material Dengan Kombinasi Metode Nwc (North West Corner) Dan Modi ( Modified Distribution) Pada Proyek Pembangunan Jembatan Di Sulawesi Utara. Jurnal Sipil Statik, 7(12), 1633-1640. https://ejournal.unsrat.ac.id /index.php/jss/article/view/26139/25776

Tamin, Ofyar. Z. 2000. Perencanaan dan Permodelan Transportasi. Bandung. Indonesia. Penerbit ITB.

Yunistira, A. (2014). SOLUSI OPTIMUM MODEL TRANSPORTASI PADA CV. MANURINDO DI MAKASSAR. 203.

Zainuddin. (2011). Analisis Penerapan Model Transportasi dan Distribusi pada PT. CocaCola Bottling Indonesia. 